\title{
1 Greenhouse gas fluxes in mangrove forest soil in the Amazon estuary
}

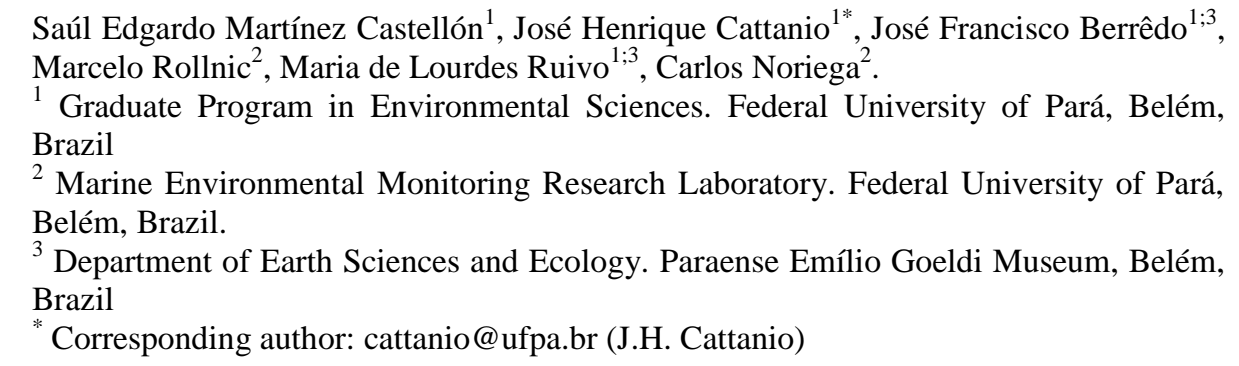

Abstract: Tropical mangrove forests are important carbon sinks, the soil being the main reservoir of this chemical element. Understanding the variability and the key factors that control fluxes is critical to account for greenhouse gas (GHG) emissions, especially in a scenario of global climate change. The current study is the first to quantify methane $\left(\mathrm{CH}_{4}\right)$ and carbon dioxide $\left(\mathrm{CO}_{2}\right)$ emissions using a dynamic chamber in Amazon natural mangrove soils. Sampling points were selected in a contrasting topographic gradient, the highest point being where flooding occurs only at high tides during the solstice and on the high tides of the rainy season of the new and full moons. The results showed that mangrove soils are sources of greenhouse gases, and $\mathrm{CO}_{2}$ fluxes were not different between seasons, and only in the dry period were they greater in the high topography. Only in the low topography, the $\mathrm{CH}_{4}$ fluxes were higher in the rainy season. However, in the dry period, the low topography soil produced more $\mathrm{CH}_{4}$. Soil organic matter, carbon and nitrogen ratio $(\mathrm{C} / \mathrm{N})$, and redox potential influenced the annual and seasonal variation of $\mathrm{CO}_{2}$ emissions; however, they did not influence $\mathrm{CH}_{4}$ flux. To account for global GHG emissions, in the Amazonian estuary mangrove soil produced $35.4 \mathrm{Mg}$ $\mathrm{CO}_{2 \text {-eq }} \mathrm{ha}^{-1} \mathrm{yr}^{-1}$.

\section{Introduction}

The Amazon coastal areas in the State of Pará (Brazil) cover $2,176.8 \mathrm{~km}^{2}$ where mangroves develop under the macro-tide regime in the (Souza Filho, 2005), representing approximately 85\% of the entire area of Brazilian mangroves (Herz, 1991). These mangrove areas are estimated to be the main contributors to greenhouse gas emissions in marine ecosystems (Allen et al., 2011; Chen et al., 2012). However, mangrove forests are highly productive due to a high nutrient turnover rate (Robertson 
mangrove forests (between $30^{\circ}$ latitude and $73^{\circ}$ longitude) revealed that these forests are the richest in carbon storage in the tropics, containing on average $1023 \mathrm{Mg} \mathrm{C} \mathrm{ha}^{-1}$ of which 49 to $98 \%$ is present in the soil (Donato et al., 2011). In addition, phenolic compounds inhibit microbial activity and help keep organic carbon intact, thus accumulating organic matter in mangrove forest soils (Friesen et al., 2018).

The production of greenhouse gases from soils is mainly attributable to biogeochemical processes. Microbial activities and gas production are related to soil properties, including total carbon and total nitrogen concentrations, moisture, porosity, salinity, and redox potential (Bouillon et al., 2008; Chen et al., 2012). Due to the dynamics of tidal movements, mangrove soils may become saturated and present a reduced oxygen availability or total aeration caused by the ebb tide. Studies attribute soil carbon flux responses to moisture perturbations because of seasonality and flooding events (Banerjee et al., 2016), with fluxes being dependent on tidal extremes (high tide and low tide), and flood duration (Chowdhury et al., 2018).

The estimated $\mathrm{CO}_{2}$ production to the atmosphere, in tropical estuarine areas, is 16.2 $\mathrm{TgCy}^{-1}$ (Alongi, 2009). However, the most recent estimate between latitude $0^{\circ}$ to $23.5^{\circ}$ $\mathrm{S}$ reveals an emission of $2.3 \mathrm{~g} \mathrm{CO}_{2} \mathrm{~m}^{-2} \mathrm{~d}^{-1}$ (Rosentreter et al., 2018a). In situ $\mathrm{CO}_{2}$ production is related to the water input of terrestrial, riparian, and groundwater brought by rainfall (Rosentreter et al., 2018c).

Due to this periodic tidal influence, the mangrove ecosystem is regularly flooded, leaving the soil anoxic and reduced, favoring methanogenesis (Dutta et al., 2013). Thus, estuaries are considered hot spots for $\mathrm{CH}_{4}$ production and emission (Bastviken et al., 2011; Borges et al., 2015). The organic material decomposition by methanogenic bacteria in anoxic environments, such as sediments, inner suspended particles, zooplankton gut (Reeburgh, 2007; Valentine, 2011), and the reduction of sulfate in anoxic marine sediments (Purvaja et al., 2004), also results in $\mathrm{CH}_{4}$ formation. On the other hand, an ecosystem with salinity levels greater than 18 ppt may show an absence of $\mathrm{CH}_{4}$ emissions (Poffenbarger et al., 2011). Currently the uncertainties in emitted $\mathrm{CH}_{4}$ values in vegetated coastal wetlands are approximately 30\% (EPA, 2017). The total emission of $0.010 \mathrm{Tg} \mathrm{CH}_{4} \mathrm{y}^{-1}$ or $0.64 \mathrm{~g} \mathrm{CH}_{4} \mathrm{~m}^{-2} \mathrm{~d}^{-1}$ was estimated between 0 and $5^{\circ}$ latitude (Rosentreter et al., 2018a).

The objective of this study is to investigate the spatial and seasonal variation in the monthly fluxes of $\mathrm{CO}_{2}$ and $\mathrm{CH}_{4}$ from the soil in a non-anthropized mangrove area in the 
Mojuim River Estuary, belonging to the Amazon biome. The environmental factors and physicochemical analysis of the soil were investigated from 2017 to 2018 to understand the gas fluxes.

\section{Material and Methods}

\subsection{Study site}

This study was conducted in the Amazonian coastal zone, Macaca Island, located in the Mojuim River estuary, at the Mocapajuba Marine Extractive Reserve, municipality of São Caetano de Odivelas (Figure 1), state of Pará (Brazil). Macaca island has an area of 1,322 ha with exclusively untouched mangrove forests, which belongs to a coastal strip of $2177 \mathrm{~km}^{2}$ in the state of Pará (Souza Filho, 2005). The climate is Am type according to the Köppen classification (Peel et al., 2007). The climatological data were obtained from the Meteorological Database for Teaching and Research of the National Institute of Meteorology (INMET). The area has a rainy season from January to June $(2,296 \mathrm{~mm}$ of precipitation) and a dry season from July to December $(687 \mathrm{~mm})$. March and April are the rainiest months with 505 and $453 \mathrm{~mm}$ of precipitation, while October and November are the driest (53 and $61 \mathrm{~mm}$, respectively). The minimum temperatures occur in the rainy period $\left(26^{\circ} \mathrm{C}\right)$ and the maximum in the dry period $\left(29^{\circ} \mathrm{C}\right)$. The Mojuim estuary has a macrotidal regime, with an average height of $4.9 \mathrm{~m}$ during spring tide and $3.2 \mathrm{~m}$ during low tide (Rollnic et al., 2018). During the wet season the Mojuim River has a flow velocity of $1.8 \mathrm{~m} \mathrm{~s}^{-1}$ at the ebb tide and $1.3 \mathrm{~m} \mathrm{~s}^{-1}$ at the flood tide. During the dry season, the maximum currents are $1.9 \mathrm{~m} \mathrm{~s}^{-1}$ at the flood and $1.67 \mathrm{~m} \mathrm{~s}^{-1}$ at the ebb tide (Rocha, 2015) The annual mean salinity is $26.95 \pm 0.98$ PSU (Valentim et al., 2018). 


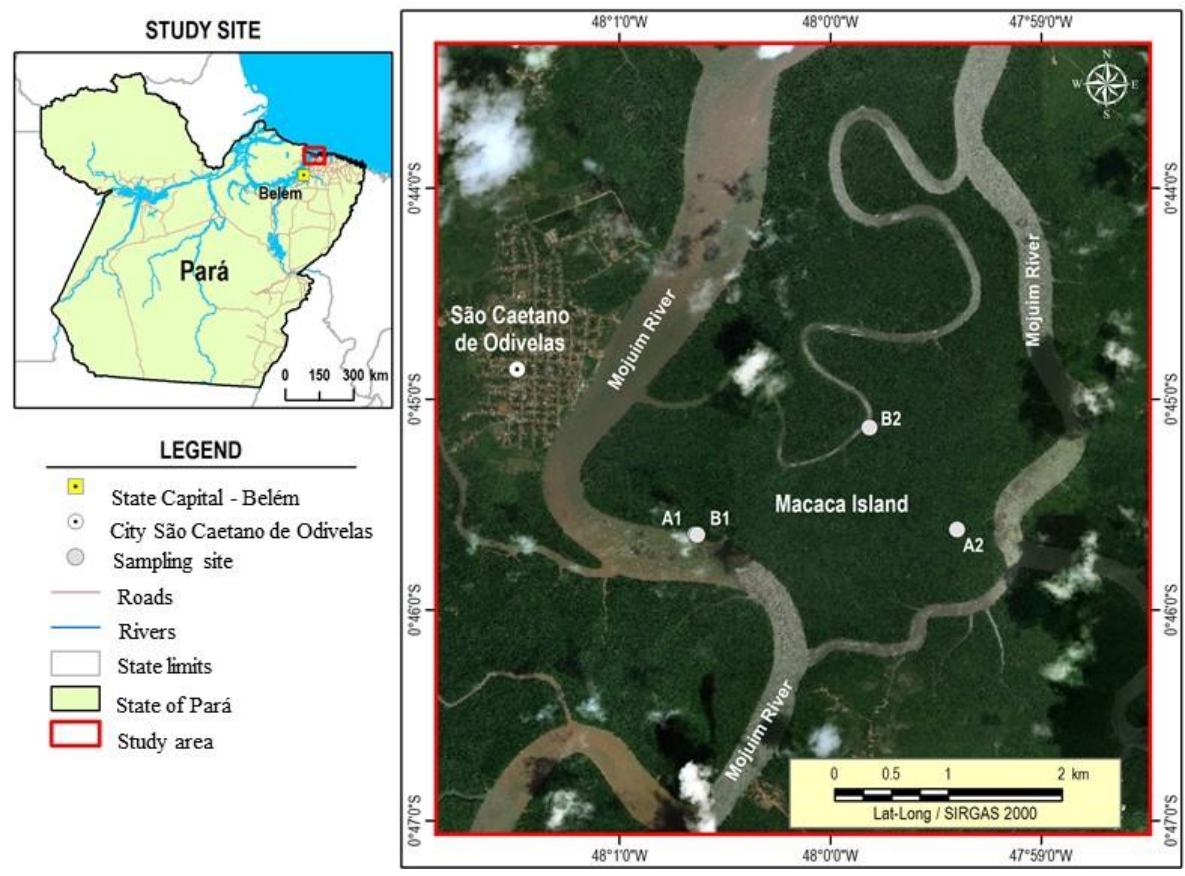

Figure 1. Macaca Island located in the mangrove coast of Northern Brazil, Municipality of São Caetano de Odivelas (state of Pará), with the sampling points at low (B1 and B2) and high topographies (A1 and A2). Image Source: (C) Google Earth

The Mojuim River region is geomorphologically formed by partially submerged river basins consequent of an increase in the relative sea level during the Holocene (Prost et al., 2001) associated with the formation of mangroves, dunes, and beaches (El-Robrini et al., 2006). This river forms the entire watershed of the municipality of São Caetano de Odivelas and borders the municipality of São João da Ponta (Figure 1). Before reaching the estuary, the Mojuim River crosses an area of a dryland forest highly fragmented by family farming, forming remnants of secondary forest (<5.0 ha) with various ages (Fernandes and Pimentel, 2019). The population economically exploited the estuary, primarily by artisanal fishing, crab (Ucides cordatus L.) extraction, and oyster farms.

Four sampling sites were selected in the Macaca Island: two where flooding occurs every day (B1 and B2; Figure 1), called low topography, and two where flooding occurs only at high tides during the solstice and on the high tides of the rainy season of the new and full moons (A1 and A2; Figure 1), called high topography. Once a month, the gas 
110 flux for each chamber was measured during periods of waning or crescent moon, as these are the times when the soil in the low topography is more exposed. The flora of the mangrove area on the Macaca Island is little anthropized and comprises the genera Rhizophora, Avicenia, Laguncularia, and Acrostichum (Ferreira, 2017; França et al.,

114 2016). The estuarine plains are influenced by a macro tide dynamics and can be physiographically divided into four sectors (França et al., 2016). The Macaca Island is classified as being from the fourth sector, which consists of woods of adult trees of the genus Ryzophora with an average height of 10 to $25 \mathrm{~m}$, located at an elevation of 0 to 5 m, with silt-clay soil (França et al., 2016).

The floristic survey was conducted at the same sites as the gas flow study, using circular plots of 1,256.6 $\mathrm{m}^{2}$ (Kauffman et al., 2013), divided into four subplots of $314.15 \mathrm{~m}^{2}$, which is the equivalent to 0.38 ha (Figure 1). All trees with DBH (diameter at breast height) greater than $0.05 \mathrm{~m}$ had their diameter above the aerial roots, the diameter of the stem, and total height recorded. The allometric equation to calculate tree biomass (AGB) was: $A G B=0.168 \times \rho \times(D B H) \times 2.471$, where $\rho$ represents wood density, using $0.87 \mathrm{~g} \mathrm{~cm}^{-3}$ for $R$. mangle and $0.72 \mathrm{~g} \mathrm{~cm}^{-3}$ for A. germinans (Howard et al., 2014b).

2.3 Soil sampling and environmental characterization

In July 2017 and January 2018, four soil samples were collected with an auger at a depth of $0.10 \mathrm{~m}$ in all the studied sites (Figure 1). Before the soil samples were removed, $\mathrm{pH}$ and redox potential $(\mathrm{Eh} ; \mathrm{mV})$ were measured with a Metrohm 744 equipment by inserting the platinum probe directly into the soil at a depth of $0.10 \mathrm{~m}$ (Bauza et al., 2002). The soil samples were properly stored and taken to the Chemical Analysis Laboratory of the Museu Paraense Emílio Goeldi. Salinity (Sal; ppt) was measured with PCE-0100, and soil moisture (Sm; \%) by the residual gravimetric method (EMBRAPA, 1997).

Organic Matter (OM; $\mathrm{g} \mathrm{kg}^{-1}$ ), Total Carbon (TC; $\mathrm{g} \mathrm{kg}^{-1}$ ) and Total Nitrogen (TN; $\mathrm{g} \mathrm{kg}^{-1}$ ) were calculated by volumetry (oxidoreduction) using the Walkley-Black method (Kalembasa and Jenkinson, 1973). Microbial carbon (Cmic; $\mathrm{mg} \mathrm{kg}^{-1}$ ) and microbial nitrogen (Nmic; $\mathrm{mg} \mathrm{kg}^{-1}$ ) were determined through the 2,0 min of Irradiation-extraction method of soil by microwave technique (Islam and Weil, 1998). Microwave heated soil 
extraction proved to be a simple, fast, accurate, reliable and safe method to measure soil microbial biomass (Araujo, 2010; Ferreira et al., 1999; Monz et al., 1991). The Cmic was determined by dichromate oxidation (Kalembasa and Jenkinson, 1973; Vance et al., 1987). The Nmic was analyzed following the method described by Brookes et al. (1985), changing fumigation to irradiation, which uses the difference between the amount of TN in irradiated and non-irradiated soil. We used the flux conversion factor of 0.33 (Sparling and West, 1988) and 0.54 (Almeida et al., 2019; Brookes et al., 1985), for carbon and nitrogen, respectively. Particle size analysis was performed separately on four soil samples collected at each flux site, in the two seasons, according to EMBRAPA (1997). .

At each flow measurement, environmental variables such as air temperature (Tair, ${ }^{\circ} \mathrm{C}$ ), relative humidity ( $\mathrm{RH}, \%)$, wind speed (Ws, $\mathrm{m} \mathrm{s}^{-1}$ ) were quantified with a portable thermo-hygrometer (model AK821) at the height of $2.0 \mathrm{~m}$ above the soil surface. Soil temperature $\left(\mathrm{Ts},{ }^{\circ} \mathrm{C}\right.$ ) was measured with a portable digital thermometer (model TP101) sequentially after each flow measurement. Daily precipitation was obtained from an automatic precipitation station installed at a pier on the banks of the Mojuim River in São Caetano das Odivelas (coordinates: 044'18.48 "S; 4800'47.94 "W).

\subsection{Fluxes Measurements}

In each plot, eight Polyvinyl Chloride rings with $0.20 \mathrm{~m}$ diameter and $0.12 \mathrm{~m}$ height were randomly installed within a circumference with a diameter of $20 \mathrm{~m}$. The rings had an area of $0.028 \mathrm{~m}^{-2}$ (volume of $3.47 \mathrm{~L}$ ) and were fixed $0.05 \mathrm{~m}$ into the ground. The height of the ring above ground was measured at four equidistant points with a ruler at each flow measurement. To avoid the influence of mangrove roots on the gas fluxes, the rings were placed in locations without any seedlings or aboveground mangrove roots. $\mathrm{CO}_{2}$ and $\mathrm{CH}_{4}$ fluxes $\left(\mathrm{g} \mathrm{CO}_{2}\right.$ or $\left.\mathrm{CH}_{4} \mathrm{~m}^{-2} \mathrm{~d}^{-1}\right)$ were measured using the dynamic chamber methodology (Norman et al., 1997; Verchot et al., 2000), sequentially connected to a Los Gatos Research portable gas analyzer (Mahesh et al., 2015). The device was calibrated monthly with high quality standard gas. The rings were sequentially closed for three minutes with a PVC cap, which enabled the connection to the analyzer via two $12.0 \mathrm{~m}$ polyethylene hoses. The gas concentration was measured ( $\mathrm{ppm}$ ) every two seconds and automatically stored by the analyzer. $\mathrm{CO}_{2}$ and $\mathrm{CH}_{4}$ fluxes were calculated from the linear regression of increasing/decreasing $\mathrm{CO}_{2}$ and $\mathrm{CH}_{4}$ concentrations within the chamber, usually between one and three minutes after the ring cover was placed 
177 2014). However, in our analyses, the vast majority of regressions reached an $R^{2}>0.70$,

178 and the regressions were weak in only $6 \%$ of the data.

$179 \quad 2.5 \quad$ Statistical analyses

180 The normality of the data of $\mathrm{FCH}_{4}$ and $\mathrm{FCO}_{2}$ and soil physicochemical parameters was

181 determined by the Shapiro-Wilks method. The student's t-test was used to test the 182 differences $(\mathrm{p}<0.05)$ in the emissions between the different sites and seasonal periods.

183 An ANOVA and Tukey's test ( $<$ < 0.05) were used when the distributions were normal.

184 For non-parametric data the Kruskal-Wallis test was used ( $\mathrm{p}<0.05)$. Pearson 185 correlation coefficients were calculated to determine the relationships between soil 186 properties and gas fluxes. Statistical analyses were performed with and free statistical 187 software Infostat 2015®.

188

189

190

191

192

193

194

195

\section{Results}

\subsection{Precipitation}

There was a marked seasonality during the study period (Figure 2), with 2,155.0 mm of precipitation during the rainy period and $1,016.5 \mathrm{~mm}$ during the dry period. However, the rainfall distribution was different from the climatological average (Figure 2). The rainy season had $553.2 \mathrm{~mm}$ less precipitation, and the dry season had $589.1 \mathrm{~mm}$ more than the climatological normal. Thus, in the period studied, the dry season was rainier, and the rainy season was drier than the climatological normal. 


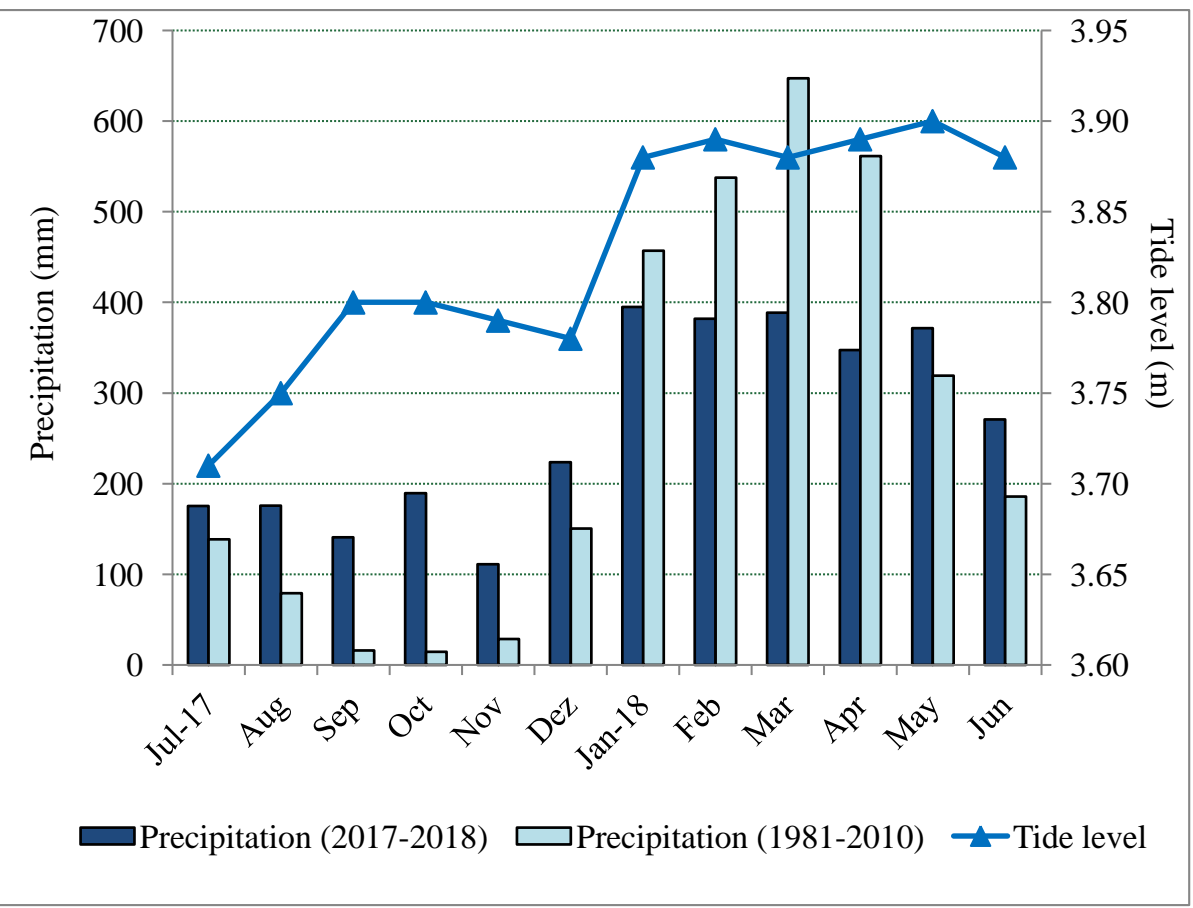

Figure 2. Monthly climatological normal in the municipality of Soure (1981-2010, mm), monthly precipitation (mm), and maximum tide height (m) for the from 2017 to 2018, in the municipality of São Caetano de Odivelas (PA).

\subsection{Carbon Dioxide and methane efflux}

The $\mathrm{CO}_{2}$ and $\mathrm{CH}_{4}$ fluxes in the mangrove soil were not normally distributed, so the statistical analysis was performed using a non-parametric method. $\mathrm{CO}_{2}$ fluxes only differed among topographies in January $(\mathrm{H}=3.915$; $\mathrm{p}=0.048)$, July $(\mathrm{H}=9.091 ; \mathrm{p}=$ $0.003)$, and November $(\mathrm{H}=11.294 ; \mathrm{p}<0.000)$ (Table 1$)$, with generally higher fluxes at the high topography than at the low topography. $\mathrm{CH}_{4}$ fluxes were statistically different between topographies only in November $(H=9.276 ; \mathrm{p}=0.002)$ and December $(\mathrm{H}=4.945 ; \mathrm{p}=0.005)$, with higher fluxes at the low topography (Table 1$)$

Table 1. Monthly and seasonal (dry and rainy seasons) fluxes of $\mathrm{CO}_{2}$ and $\mathrm{CH}_{4}\left(\mathrm{~g} \mathrm{CO}_{2}\right.$ or $\mathrm{CH}_{4} \mathrm{~m}^{-2} \mathrm{~d}^{-1}$ ) at the high and low topographies. Numbers represent the mean (standard error). Lower case letters compare topographies in the same month. Upper case letters compare stations at each topography. Different boldface letters have statistically significant variation (Kruskal Wallis, $\mathrm{p}<0.05$ ). 


\begin{tabular}{|c|c|c|c|c|}
\hline & \multicolumn{2}{|c|}{$\mathrm{CO}_{2}$ flux $\left(\mathrm{g} \mathrm{m}^{-2} \mathrm{~d}^{-1}\right)$} & \multicolumn{2}{|c|}{$\mathrm{CH}_{4}$ flux $\left(\mathrm{g} \mathrm{m}^{-2} \mathrm{~d}^{-1}\right)$} \\
\hline & High topography & Low topography & High topography & Low topography \\
\hline July/2017 & $10.166(1.555)^{a}$ & $4.036(1.027)^{b}$ & $0.0724(0.0518)^{\mathrm{a}}$ & $0.2129(0.2087)^{\mathrm{a}}$ \\
\hline August & $8.513(2.672)^{\mathrm{a}}$ & $12.462(3.400)^{\mathrm{a}}$ & $0.0033(0.0016)^{\mathrm{a}}$ & $0.1270(0.1185)^{\mathrm{a}}$ \\
\hline September & $11.506(2.515)^{\mathrm{a}}$ & $6.020(1.207)^{\mathrm{a}}$ & $0.0014(0.0008)^{\mathrm{a}}$ & $0.1738(0.1608)^{\mathrm{a}}$ \\
\hline October & $4.147(0.653)^{\mathrm{a}}$ & $3.993(0.731)^{\mathrm{a}}$ & $0.0000(0.0000)^{\mathrm{a}}$ & $-0.0004(0.0056)^{\mathrm{a}}$ \\
\hline November & $7.648(1.064)^{\mathrm{a}}$ & $0.007(0.002)^{b}$ & $-0.0004(0.0001)^{b}$ & $0.1395(0.0708)^{\mathrm{a}}$ \\
\hline December & $5.302(1.176)^{\mathrm{a}}$ & $7.622(2.505)^{\mathrm{a}}$ & $0.0009(0.0009)^{b}$ & $0.1210(0.0575)^{\mathrm{a}}$ \\
\hline Dry period & $7.902(0.803)^{\mathrm{aA}}$ & $6.202(0.895)^{b A}$ & $0.0141(0.010)^{b B}$ & $0.1280(0.053)^{\mathrm{aA}}$ \\
\hline January/2018 & $6.697(1.717)^{\mathrm{a}}$ & $2.995(0.493)^{b}$ & $0.0007(0.0004)^{\mathrm{a}}$ & $0.0294(0.0183)^{\mathrm{a}}$ \\
\hline February & $9.053(2.650)^{\mathrm{a}}$ & $6.384(1.428)^{\mathrm{a}}$ & $0.0049(0.0022)^{\mathrm{a}}$ & $0.8743(0.7024)^{\mathrm{a}}$ \\
\hline March & $5.225(1.135)^{\mathrm{a}}$ & $5.970(1.534)^{\mathrm{a}}$ & $0.0077(0.0056)^{\mathrm{a}}$ & $0.3736(0.2197)^{\mathrm{a}}$ \\
\hline April & $14.077(4.695)^{\mathrm{a}}$ & $4.785(0.711)^{\mathrm{a}}$ & $0.1968(0.1304)^{\mathrm{a}}$ & $0.0372(0.2841)^{\mathrm{a}}$ \\
\hline May & $3.299(0.587)^{\mathrm{a}}$ & $3.565(0.472)^{\mathrm{a}}$ & $0.0014(0.0019)^{\mathrm{a}}$ & $0.0218(0.5648)^{\mathrm{a}}$ \\
\hline June & $8.796(2.053)^{\mathrm{a}}$ & $4.704(1.183)^{\mathrm{a}}$ & $0.0226(0.0191)^{\mathrm{a}}$ & $0.6739(0.6665)^{\mathrm{a}}$ \\
\hline Rainy & $7.858(1.058)^{\mathrm{aA}}$ & $4.734(0.440)^{\mathrm{aA}}$ & $0.0390(0.023)^{\mathrm{aA}}$ & $0.3350(0.194)^{\mathrm{aA}}$ \\
\hline
\end{tabular}

213

At the high topography, $\mathrm{CO}_{2}$ fluxes were significantly higher in July compared to August and December, March, October, and May, not differing from the other months of the year $(\mathrm{H}=24.510 ; \mathrm{p}=0.011)$. $\mathrm{CH}_{4}$ fluxes at the high topography were significantly $(\mathrm{H}=40.073 ; \mathrm{p}<0.001)$ higher in April and July compared to the other months studied, and in November there was consumption of $\mathrm{CH}_{4}$ from the atmosphere (Table 1). At the low topography, $\mathrm{CO}_{2}$ fluxes were statistically $(\mathrm{H}=19.912 ; \mathrm{p}=0.046)$ higher in September and February compared to January and November, not differing from the other months. $\mathrm{CH}_{4}$ fluxes at the low topography did not show a significant variation between months $(\mathrm{H}=10.114 ; \mathrm{p}=0.407)$.

Although seasonal $\mathrm{CO}_{2}$ fluxes were higher at the high topography than at the low topography (Table 1), they were only statistically different in the dry season $(\mathrm{H}=7.378$; $\mathrm{p}=0.006$ ). In contrast, seasonal $\mathrm{CH}_{4}$ fluxes were higher at the low topography (Table 1) but were only statistically different in the dry season $(H=8.229 ; \mathrm{p}<0.001)$. With this the mean annual fluxes of $\mathrm{CO}_{2}$ and $\mathrm{CH}_{4}$ were $6.659 \pm 0.419 \mathrm{~g} \mathrm{CO}_{2} \mathrm{~m}^{-2} \mathrm{~d}^{-1}$ (mean \pm standard error) and $0.132 \pm 0.053 \mathrm{~g} \mathrm{CH}_{4} \mathrm{~m}-2 \mathrm{~d}-1$, respectively. 
229 Silt concentration was higher at the low topography (LSD: $14.763 ; \mathrm{p}=0.007$ ) and clay

230 concentration was higher at the high topography sites (LSD: 12.463; p=0.005), in both

231 stations studied (Table 2). Soil particle size analysis did not vary statistically $(\mathrm{p}>0.05)$

232 between the two stations (Table 2). Soil moisture did not vary significantly $(\mathrm{p}>0.05)$

233 between topographies at each station, or between seasonal periods at the same

234 topography (Table 2 ). The variable $\mathrm{pH}$ varied statistically only at the low topography

235 when the two stations were compared (LSD: 5.950; $\mathrm{p}=0.006$ ), being more acidic in the

236 dry period (Table 2). On average $\mathrm{pH}$ was significantly (LSD: 0.559; $\mathrm{p}=0.008$ ) higher in

237 the dry season (Table 2). No variation in Eh was identified between topographies and

238 seasons (Table 2), although it was higher in the dry season than in the rainy season.

239 However, Sal values were higher (LSD: $3.444 ; \mathrm{p}=0.010$ ) at the high topography than at

240 the low topography in the dry season (Table 2). In addition, Sal was significantly higher

241 in the dry season in both the high (LSD: 2.916; $\mathrm{p}<0.001$ ) and low (LSD: 3.003; $\mathrm{p}<$

242 0.001) topographies (Table 2). 
248 The Cmic did not differ between topographies in the two seasons (Table 3); however

249 CT was significantly higher in the low topography in the dry season (LSD: 5.589; p <

250 0.000) and in the rainy season (LSD: 5.777; $\mathrm{p}=0.024$ ). In addition, Cmic was higher in

251 the dry season in both the high (LSD: 11.325; p < 0.010) and low (LSD: 9.345; p <

2520.000 ) topographies (Table 3). Nmic did not vary between topographies seasonally.

253 However, Nmic in the high (LSD: 9.059; $\mathrm{p}=0.013$ ) and low topographies (LSD: 4.447;

$254 \mathrm{p}=0.001$ ) was higher during the dry season (Table 3). The $\mathrm{C} / \mathrm{N}$ ratio (Table 3) was

255 higher in the low topography in both the dry (LSD: 3.142; $\mathrm{p}<0.000$ ) and rainy seasons

256 (LSD: $3.675 ; p=0.033$ ), when compared to the high topography. However, only in the

257 low topography was the $\mathrm{C} / \mathrm{N}$ ratio higher (LSD: $1.863 ; \mathrm{p}<0.000$ ) in the dry season

258 compared to the rainy season (Table 3). Soil MO was higher at the low topography in

259 the rainy (LSD: 9.950; $\mathrm{p}=0.024$ ) and in the dry seasons (LSD: 9.630; $p<0.000$ ).

260 However, only in the lowland topography was the MO concentration higher in the dry

261 season than in the rainy season (Table 3). 
266 Tar was significantly higher $(\mathrm{LSD}=0.72, \mathrm{p}=0.01)$ at the high topography $(31.24 \pm$ $0.26^{\circ} \mathrm{C}$ ) than at the low topography $\left(30.30 \pm 0.25^{\circ} \mathrm{C}\right)$ only in the rainy season (Figure 3a). No significant variation in Ts was found between the topographies in both seasons (Figure $3 b)$. The RH was significantly higher $(\mathrm{LSD}=2.55, \mathrm{p}=0.01$ ) at the high topography $(70.54 \pm 0.97 \%)$ than at the low topography $(66.85 \pm 0.87 \%)$ only in the rainy season (Figure 3c). At this same station, Vv (Figure 3d) was significantly higher $(\mathrm{LSD}=0.15, \mathrm{p}<0.00)$ at the low topography $\left(0.54 \pm 0.06 \mathrm{~m} \mathrm{~s}^{-1}\right)$ than at the high topography $\left(0.24 \pm 0.04 \mathrm{~m} \mathrm{~s}^{-1}\right)$.

(a)

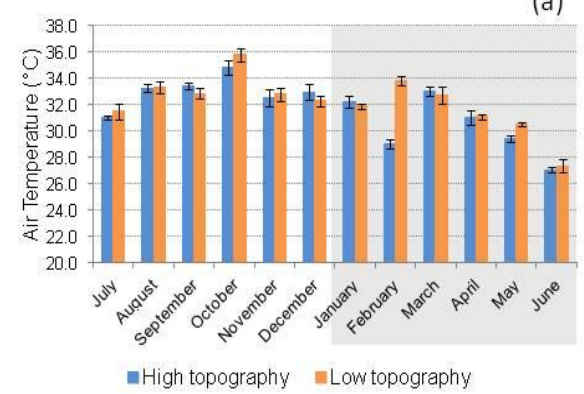

(c)

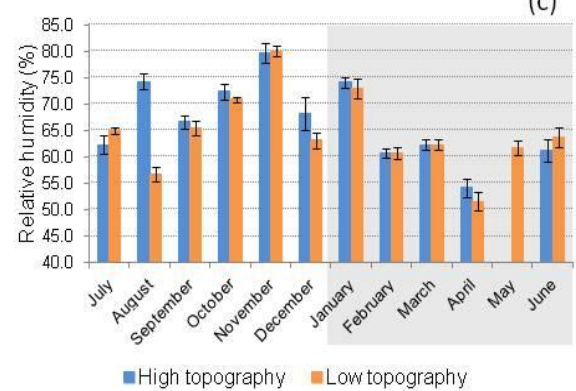

(b)

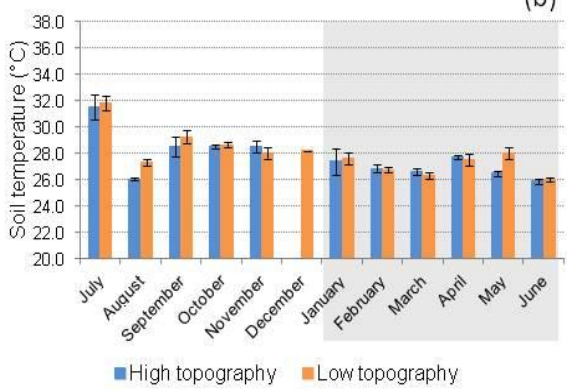

(d)

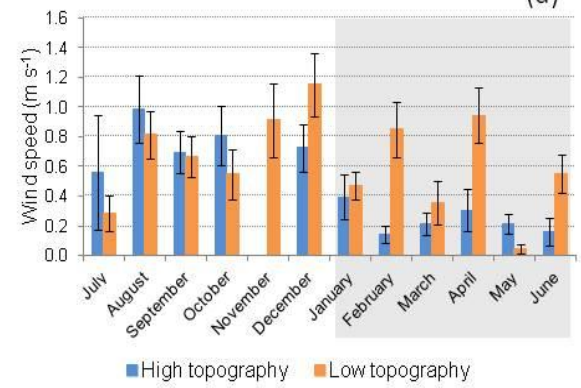

Figure 3. a) Air temperature $\left({ }^{\circ} \mathrm{C}\right)$, b) soil temperature $\left({ }^{\circ} \mathrm{C}\right)$, c) relative humidity $(\%)$ and d) wind speed $\left(\mathrm{m} \mathrm{s}^{-1}\right)$ at high and low topographies, from July 2017 to June 2018 in a mangrove area in the Mojuim River estuary. Bars highlighted in grey correspond to the rainy season $(n=16)$. The bars represent the standard error.

Only the species $R$. mangle and A. germinans were found in the floristic survey carried out. The DBH did not vary significantly between the topographies for either species (Table 4). However, $R$. mangle had a higher DBH than A. germinaris at both high 
https://doi.org/10.5194/bg-2021-325

Preprint. Discussion started: 4 February 2022

(C) Author(s) 2022. CC BY 4.0 License.

(c) (i)

283 (LSD: 139.304; $\mathrm{p}=0.037$ ) and low topographies (LSD: 131.307; $\mathrm{p}=0.001$ ). The basal

284 area (BA) and AGB variables did not show significant variation (Table 4). A total

285 aboveground biomass of $322.1 \pm 49.6 \mathrm{Mg} \mathrm{ha}^{-1}$ was estimated. 


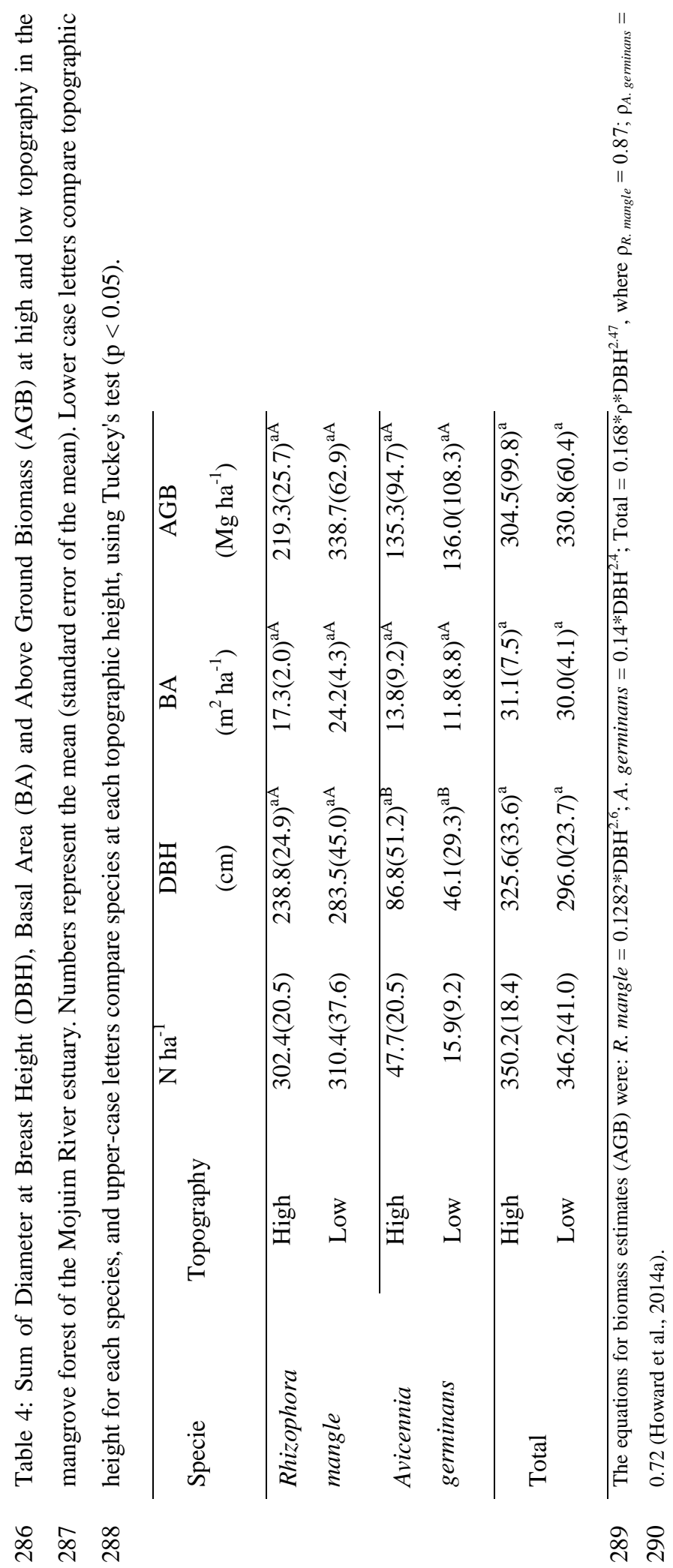




\section{Discussion}

292 4.1 Carbon dioxide e methane flux measurements

293 It is important to consider that the year under study was rainier in the dry season and less rainy in the wet season (Figure 2). Perhaps this variation is already related to the effects of global climate changes. Under these conditions, the $\mathrm{CO}_{2}$ flux from the mangrove soil ranged from -5.06 to $68.96 \mathrm{~g} \mathrm{CO}_{2} \mathrm{~m}^{-2} \mathrm{~d}^{-1}$ (mean $6.66 \mathrm{~g} \mathrm{CO}_{2} \mathrm{~m}^{-2} \mathrm{~d}^{-1}$ ), while the $\mathrm{CH}_{4}$ flux ranged from -5.07 to $11.08 \mathrm{~g} \mathrm{CH}_{4} \mathrm{~m}^{-2} \mathrm{~d}^{-1}$ (mean $0.13 \mathrm{~g} \mathrm{CH}_{4} \mathrm{~m}^{-2} \mathrm{~d}^{-1}$ ), resulting in a total carbon rate of $7.04 \mathrm{~g} \mathrm{CO}_{2} \mathrm{~m}^{-2} \mathrm{~d}^{-1}$ or $25.70 \mathrm{Mg} \mathrm{CO}_{2}$ ha $^{-1} \mathrm{y}^{-1}$ (negative values represent atmospheric consumption of the gas) (Figure 4). The negative $\mathrm{CO}_{2}$ flux appears to be a consequence of the increased $\mathrm{CO}_{2}$ solubility in tidal waters, or of the increased sulfate reduction (Borges et al., 2018; Chowdhury et al., 2018; Nóbrega et al., 2016). The soil carbon flux in mangrove area in the Amazon region was within the range of findings for other tropical mangrove areas (2.57 to $11.00 \mathrm{~g} \mathrm{CO}_{2} \mathrm{~m}^{-2} \mathrm{~d}^{-1}$; Shiau and Chiu, 2020). However, the mean flux of $6.2 \mathrm{mmol} \mathrm{CO}_{2} \mathrm{~m}^{-2} \mathrm{~h}^{-1}$ recorded in this Amazonian mangrove was much higher than the mean efflux of $2.9 \mathrm{mmol} \mathrm{CO}_{2} \mathrm{~m}^{-2} \mathrm{~h}^{-1}$ recorded in 75 mangroves during low tide periods (Alongi, 2009). We found a mean monthly flux of $327.9 \pm 78.0 \mathrm{mg} \mathrm{CO}_{2} \mathrm{~m}^{-2} \mathrm{~h}^{-1}$ and $217.2 \pm 51.0 \mathrm{mg} \mathrm{CO}_{2} \mathrm{~m}^{-2} \mathrm{~h}^{-1}$, at the high and low topography, respectively. 

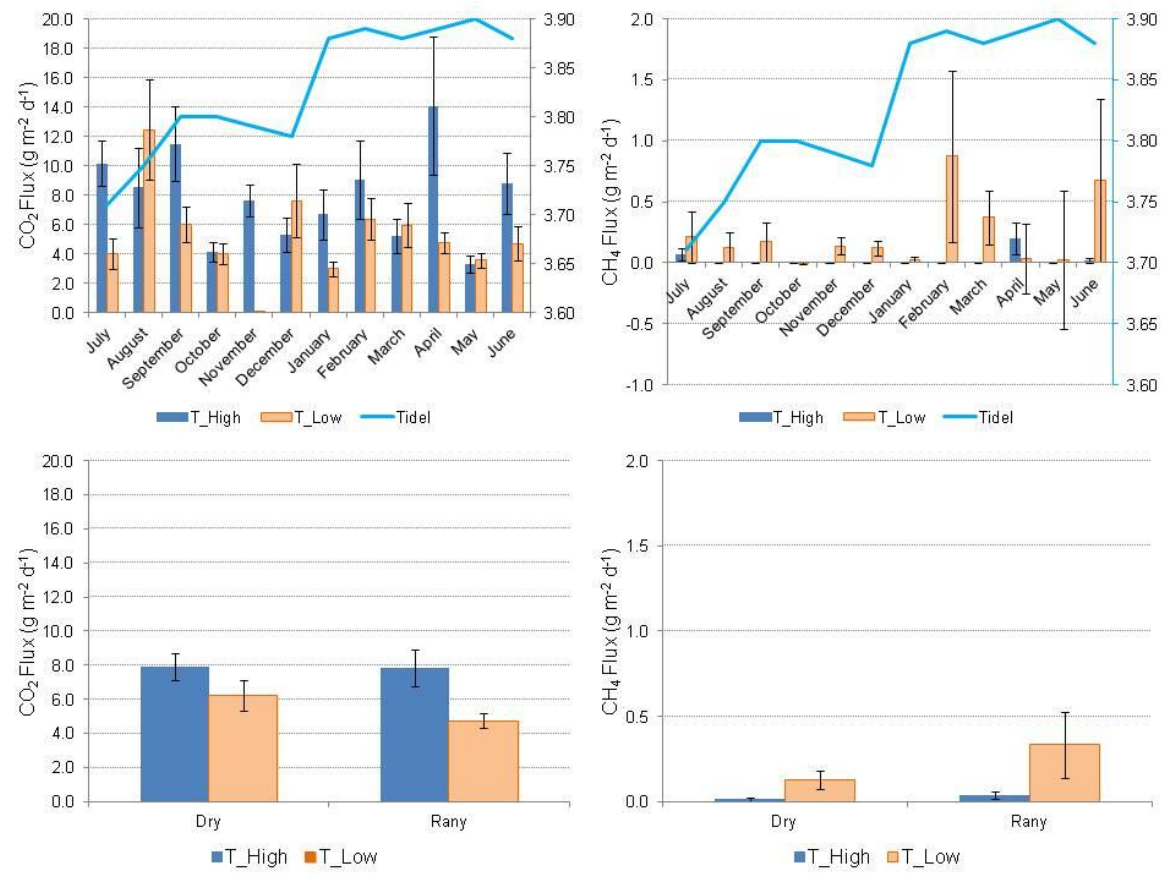

Figure 4. $\mathrm{CO}_{2}$ and $\mathrm{CH}_{4}$ fluxes $\left(\mathrm{g} \mathrm{CO}_{2}\right.$ or $\mathrm{CH}_{4} \mathrm{~m}^{-2} \mathrm{~d}^{-1}$ ) monthly (July 2018 to June 2019) $(\mathrm{n}=16)$ and seasonally (Dry and Rany), at high (T_High) and low (T_Low) topographies $(n=96)$, in mangrove forest soil compared to tide level (TideL). The bars represent the standard error of the mean.

An emission of 0.010 Tg CH $\mathrm{y}^{-1}, 0.64 \mathrm{~g} \mathrm{CH}_{4} \mathrm{~m}^{-2} \mathrm{~d}^{-1}$ (Rosentreter et al., 2018b), or 26.7 $\mathrm{mg} \mathrm{CH} \mathrm{CH}^{-2} \mathrm{~h}^{-1}$ is estimated at tropical latitudes ( 0 and $5^{\circ}$ ). In our study, the monthly average in $\mathrm{CH}_{4}$ flux was higher at the low topography $\left(7.3 \pm 8.0 \mathrm{mg} \mathrm{C} \mathrm{m}^{-2} \mathrm{~h}^{-1}\right)$ than at the high topography $\left(0.9 \pm 0.6 \mathrm{mg} \mathrm{C} \mathrm{m}^{-2} \mathrm{~h}^{-1}\right)$ (Figure 4). Therefore, the $\mathrm{CH}_{4}-\mathrm{C}$ fluxes from the mangrove soil in the Mojuim River estuary were much lower than expected. The average emission from the soil of $8.4 \mathrm{mmol} \mathrm{CH}_{4} \mathrm{~m}^{-2} \mathrm{~d}^{-1}$ was well below the fluxes recorded in the Bay of Bengal, with $18.4 \mathrm{mmol} \mathrm{CH}_{4} \mathrm{~m}^{-2} \mathrm{~d}^{-1}$ (Biswas et al., 2007). In the Amazonian mangrove studied the mean annual carbon equivalent efflux was $429.6 \mathrm{mg}$ $\mathrm{CO}_{2 \text {-eq }} \mathrm{m}^{-2} \mathrm{~h}^{-1}$. This value is $0.00004 \%$ of the erosion losses of $103.5 \mathrm{Tg} \mathrm{CO}_{2 \text {-eq }} \mathrm{ha}^{-1} \mathrm{y}^{-1}$ projected for the next century in tropical mangrove forests (Adame et al., 2021).

\subsection{Mangrove biomass}

Assuming that the amount of carbon stored is 0.42 of the total biomass (Sahu and 
127.9 and 138.9 $\mathrm{Mg} \mathrm{C} \mathrm{ha}^{-1}$ at the high and low topography, respectively. This result is well below the $507.8 \mathrm{Mg} \mathrm{C}^{-1}$ estimated for Brazilian mangroves (Hamilton and Friess, 2018), but are near the $103.7 \mathrm{Mg} \mathrm{C}^{-1}$ estimated for a mangrove at Dos Guarás island (Salum et al., 2020), 108.4 $\mathrm{Mg} \mathrm{C}^{-1}$ for the Bragantina region (Gardunho, 2017), and 132.3 Mg Mg C ha ${ }^{-1}$ in French Guiana (Fromard et al., 1998). The estimated primary production for tropical mangrove forests is $218 \pm 72 \mathrm{Tg} \mathrm{C}$ y (Bouillon et al., 2008). These results show that the mangroves of the Amazon estuary are more productive than previously known (Bouillon et al., 2008).

\subsection{Topography variation}

The mangrove areas are periodically flooded, with a larger flood volume during the ebb tides, especially in the rainy season. The hydrological condition of the soil is determined by the microtopography and can regulate the respiration of microorganisms (aerobic or anaerobic), being a decisive factor in controlling the $\mathrm{CO}_{2}$ efflux (Dai et al., 2012; Davidson et al., 2000; Ehrenfeld, 1995). In the two climatic periods of the year, the high topography produced more $\mathrm{CO}_{2}\left(7,869 \pm 1,873 \mathrm{~g} \mathrm{CO}_{2} \mathrm{~m}^{-2} \mathrm{~d}^{-1}\right)$ than the low topography $\left(5,212 \pm 1,225 \mathrm{~g} \mathrm{CO}_{2} \mathrm{~m}^{-2} \mathrm{~d}^{-1}\right)$ (Figure 4). No significant influence on $\mathrm{CO}_{2}$ flux was observed due to the low variation in high tide level throughout the year $(0.19 \mathrm{~m})$ (Figure 4), although it was numerically higher at the high topography. However, tidal height and the rainy season resulted in a higher $\mathrm{CO}_{2}$ flux (rate high/low =1.7) at the high topography $\left(7.858 \pm 0.039 \mathrm{~g} \mathrm{CO}_{2} \mathrm{~m}^{-2} \mathrm{~d}^{-1}\right)$ than at the low topography $(4.734 \pm 0.335 \mathrm{~g}$ $\mathrm{CO}_{2} \mathrm{~m}^{-2} \mathrm{~d}^{-1}$ ) (Figure 4; Table 1). This result is because the root systems of most floodtolerant plants remain active when flooded (Angelov et al., 1996). Still, the high topography has longer flood-free periods, because this only happens when the tides are in the form of triangle or when the rains are torrential.

$\mathrm{CO}_{2}$ efflux was higher in the high topography than in the low topography, i.e., $39.8 \%$ lower in the forest soil exposed to the atmosphere for less time, in the rainy season (when soils are more subject to inundation). Measurements performed on 62 mangrove forest soils showed an average flux of $2.87 \mathrm{mmol} \mathrm{CO}_{2} \mathrm{~m}^{-2} \mathrm{~h}^{-1}$ when the soil is exposed to the atmosphere, while 75 results on flooded mangrove forest soils showed an average emission of $2.06 \mathrm{mmol} \mathrm{CO}_{2} \mathrm{~m}^{-2} \mathrm{~h}^{-1}$ (Alongi, 2007, 2009), i.e., 28.2\% less than for the dry soil. Reflecting the more significant facility gases have for molecular diffusion than fluids, and the increased surface area for aerobic respiration and chemical oxidation during air exposure (Chen et al., 2010). Some studies attribute this variation to the 
temperature of the soil when exposed to tropical air (Alongi, 2009), increasing the export of dissolved inorganic carbon (Maher et al., 2018). However, although there was no significant variation in soil temperature between topographies at each time of year (Figure $3 b$ ), there was a positive correlation (Pearson $=0.15, \mathrm{p}=0.05)$ between $\mathrm{CO}_{2}$ efflux and soil temperature at the low topography.

In the rainy season, $\mathrm{CO}_{2}$ efflux was correlated with Tar (Pearson $\left.=0.23, \mathrm{p}=0.03\right), \mathrm{RH}$ $($ Pearson $=-0.32, \mathrm{p}<0.00)$ and Ts $($ Pearson $=0.21, \mathrm{p}=0.04)$ only at the low topography. In the dry season $\mathrm{CO}_{2}$ flux was correlated with Ts (Pearson $=0.39, \mathrm{p}<$ 0.00) at low topography. Some studies show that $\mathrm{CH}_{4}$ efflux is a consequence of the seasonal temperature variation in mangrove forest in temperate/monsoon climate (Chauhan et al., 2015; Purvaja and Ramesh, 2001; Whalen, 2005). However, in this study $\mathrm{CH}_{4}$ efflux was correlated with Ta $($ Pearson $=-0.33$, $\mathrm{p}<0.00)$ and $\mathrm{RH}($ Pearson $=$ $0.28, \mathrm{p}=0.01$ ) only in the dry season and at the low topography. These results show that hardly does only one physical parameter interfere with the fluxes, and that they do not interact similarly in a different topography and seasonality.

A compilation of several studies showed that the total $\mathrm{CH}_{4}$ emissions from soil in mangrove ecosystem range from 0 to $23.68 \mathrm{mg} \mathrm{C} \mathrm{m}^{-2} \mathrm{~h}^{-1}$ (Shiau and Chiu, 2020), and our study showed a range of -0.01 to $31.88 \mathrm{mg} \mathrm{C} \mathrm{m}^{-2} \mathrm{~h}^{-1}$, with a mean of $4.70 \pm 5.00 \mathrm{mg}$ $\mathrm{C} \mathrm{m}^{-2} \mathrm{~h}^{-1}$. The monthly $\mathrm{CH}_{4}$ fluxes were generally higher at the low $(0.232 \pm 0.256)$ than at the high $(0.026 \pm 0.018)$ topography, especially during the high tide (Figure 4$)$. Compared to the high topography, only in the dry season was there a significantly higher production at the low topography (Table 1, Figure 4). The low topography produced $0.0249 \mathrm{~g} \mathrm{C} \mathrm{m}^{-2} \mathrm{~h}^{-1}$ more to the atmosphere in the rainy season than in the dry season (Table 1), and the same seasonal variation was recorded in other studies (Cameron et al., 2021).

The mangrove soil in the Mojuim River estuary is rich in silt and clay (Table 2), which reduces sediment porosity and fosters the formation and retention of anoxic conditions (Dutta et al., 2013). In addition, the lack of oxygen in the flooded mangrove soil generates microbial processes such as denitrification, sulfate reduction, methanogenesis, and redox reactions (Alongi and Christoffersen, 1992). Furthermore, plenty of the $\mathrm{CH}_{4}$ produced in wetlands is dissolved in situ in the pore water caused by the high pressure, which can result in supersaturation in the water, enabling $\mathrm{CH}_{4}$ to be released from the sediment to the atmosphere by diffusion and by boiling in the water (Neue et al., 1997). 
Only the species $R$. mangle and A. germinans were found in the floristic survey carried out, which agrees with other studies in the same region (Menezes et al., 2008). Thus, the variations found in the flux between the topographies in the Mojuim River estuary are not related to the mangrove forest structure because there was no significant difference in the aboveground biomass. Since there was no difference in the species composition, it is expected that the belowground biomass would not be different either (Table 4).

Soil moisture in the Mojuim River mangrove forest negatively influenced $\mathrm{CO}_{2}$ flux in both seasons (Table 5). However a correlation with the flux of $\mathrm{CH}_{4}$ was not identified. Studies show that $\mathrm{CO}_{2}$ flux tends to be lower with high soil saturation (Chanda et al., 2014; Kristensen et al., 2008). A total of $395 \mathrm{Mg} \mathrm{C} h^{-1}$ was found at the soil surface $(0.15 \mathrm{~m})$ in the mangrove of the Mojuim River estuary, which was slightly higher than the $340 \mathrm{Mg} \mathrm{C}$ ha $^{-1}$ found in mangroves in the Amazon (Kauffman et al., 2018), however being significantly 1.8 times greater at the low topography (Table 3 ). The finer soil texture at the low topography (Table 2) reduces groundwater drainage which facilitates the accumulation of $C$ in the soil (Schmidt et al., 2011).

\subsection{Biogeochemical parameters}

Chemical parameters of the soil were better correlated with $\mathrm{CO}_{2}$ efflux in the dry period, while the $\mathrm{C}: \mathrm{N}$ ratio, $\mathrm{OM}$, and Eh were correlated with $\mathrm{CO}_{2}$ efflux in both seasons (Table 5). During the seasonal and annual periods, $\mathrm{CH}_{4}$ efflux was not correlated significantly with chemical parameters (Table 5), similar to the observed in another study (Chen et al., 2010). Increased soil moisture reduces gas diffusion rates, which directly affects the physiological state and microbial activities, by limiting the supply of the dominant electron acceptors, such as oxygen, and gases such as $\mathrm{CH}_{4}$ (Blagodatsky and Smith, 2012). The importance of soil moisture was evident in the richness and diversity of bacterial communities in a study comparing the different pore spaces filled with water (Banerjee et al., 2016). Furthermore, sulfate reduction in flooded soils (another pathway of organic matter metabolism) is dependent on the redox potential of the soil. However no sulfate reduction occurs when the redox potential has values above -150 mv (Connell and Patrick, 1968). In our study Eh was above $36.0 \mathrm{mV}$, this indicates that sulfate reduction probably did not influence the OM metabolism.

On the other hand, increasing soil moisture provides the microorganisms with essential substrates such as ammonium, nitrate, and soluble organic carbon, and increases gas diffusion rates in the water (Blagodatsky and Smith, 2012). Biologically available 
426 nitrogen often limits marine productivity (Bertics et al., 2010), and thus can affect the 427 fluxes of $\mathrm{CO}_{2}$ to the atmosphere. A higher concentration of Cmic and Nmic in the dry 428 period (Table 3), both in the high and low topographies, indicated that microorganisms 429 are more active when the soil spends more time aerated in the dry period (Table 3 ), the 430 period in which the high tides produce anoxia in the mangrove soil. Additionally, the $431 \mathrm{C} / \mathrm{N}$ ratio was well below 40, indicating that soil microorganisms and roots do not 432 compete for nitrogen (Stevenson and Cole, 1999).

433 Sulfate-reducing bacteria $\left(\mathrm{SO}_{4}{ }^{2-}\right)$ are important diazotrophs in coastal ecosystems and 434 can contribute with significant nitrogen $\left(\mathrm{N}_{2}\right)$ fixation in mangrove ecosystems (Bertics 435 et al., 2010; Shiau et al., 2017; Welsh et al., 1996). The negative correlation between $436 \mathrm{TC}, \mathrm{NT}, \mathrm{C} / \mathrm{N}$, and MO, along with the positive correlation of Nmic with soil $\mathrm{CO}_{2}$ flux 437 (Table 5), in the dry period, indicates that microbial activity is a decisive factor for $\mathrm{CO}_{2}$ 438 efflux (Poungparn et al., 2009). The high MO concentration at the two topographic 439 heights (Table 3), at the two stations studied, and the respective negative correlation 440 with $\mathrm{CO}_{2}$ flux (Table 5) confirm the importance of microbial activity in mangrove soil 441 (Gao et al., 2020). Also, $\mathrm{CH}_{4}$ produced in flooded soils can be converted mainly to $\mathrm{CO}_{2}$ 442 by the anaerobic oxidation of $\mathrm{CH}_{4}$ (Boetius et al., 2000; Milucka et al., 2015) which 443 may contribute to the higher $\mathrm{CO}_{2}$ efflux in the Mojuim River estuary compared to other 444 tropical mangroves (Rosentreter et al., 2018c). The belowground C stock is considered 445 the largest $\mathrm{C}$ reservoir in mangrove ecosystem resulting from the low rate of OM 446 decomposition due to flooding (Marchand, 2017). 
450 The higher water salinity in the dry season (Table 2) seems to result in a lower $\mathrm{CH}_{4}$ flux at the low topography, more influenced by the tidal movement in this season (Dutta et al., 2013; Lekphet et al., 2005; Shiau and Chiu, 2020). Another essential factor for the reduced $\mathrm{CH}_{4}$ emissions is when $\mathrm{SO}_{4}{ }^{2-}$ in the brine affects the competition between $\mathrm{SO}_{4}{ }^{2-}$ reduction and methanogenic fermentation, because the sulfate-reducing bacteria are more efficient in hydrogen utilization than the methanotrophic bacteria (Abram and Nedwell, 1978; Kristjansson et al., 1982). At high $\mathrm{SO}_{4}{ }^{2-}$ concentrations methanotrophic bacteria use $\mathrm{CH}_{4}$ as an energy source and oxidize it to $\mathrm{CO}_{2}$ (Coyne, 1999; Segarra et al., 2015), increasing the $\mathrm{CO}_{2}$ efflux and reducing the $\mathrm{CH}_{4}$ efflux (Megonigal and Schlesinger, 2002; Roslev and King, 1996). This may explain the high $\mathrm{CO}_{2}$ efflux found throughout the year at the high and, especially, at the low topography (Figure 4). Only in the rainy season was a significant correlation recorded between salinity and $\mathrm{CO}_{2}$ flux. Still, in all seasonal periods the correlation between salinity and $\mathrm{CO}_{2}$ and $\mathrm{CH}_{4}$ fluxes were negative.

Studies in other coastal ecosystems have recorded that methanotrophic bacteria can be sensitive to soil $\mathrm{pH}$, and reported an optimal growth at $\mathrm{pH}$ ranging from 6.5 to 7.5 (Shiau et al., 2018). The higher soil acidity in the Mojuim River wetland (Table 2) may be inhibiting the activity of methanogenic bacteria by increasing the population of methanotrophic bacteria, which are efficient in consuming $\mathrm{CH}_{4}$ (Chen et al., 2010; Hegde et al., 2003; Shiau and Chiu, 2020). In addition, the pneumatophores present in $R$. mangle increase soil aeration and reduce $\mathrm{CH}_{4}$ emissions (Allen et al., 2011; He et al., 2019). Spatial differences (topography) in $\mathrm{CH}_{4}$ emissions in the soil can be attributed to substrate heterogeneity, salinity, and the abundance of methanogenic and methanotrophic bacteria (Gao et al., 2020). The high Eh values found in both topographies, mainly in the dry period (Table 2), are unfavorable for $\mathrm{CH}_{4}$ emission. Soil Eh above $-150 \mathrm{mV}$ was considered limiting for $\mathrm{CH}_{4}$ production (Yang and Chang, 1998). Increases in $\mathrm{CH}_{4}$ efflux with reduced salinity were found due to intense oxidation or reduced competition from the more energetically efficient $\mathrm{SO}_{4}{ }^{2-}$ and $\mathrm{NO}^{3-}$ reducing bacteria than the methanogenic bacteria (Biswas et al., 2007). This fact can be observed in the $\mathrm{CH}_{4}$ efflux in the mangrove of the Mojuim River, because in the rainy season (Figure 4), when there is a reduced water salinity (Table 2) due to increased precipitation, there was an increased $\mathrm{CH}_{4}$ production, especially in the low topography 
482

(Figure 4). However, we did not find a correlation between $\mathrm{CH}_{4}$ efflux and salinity, as already reported (Purvaja and Ramesh, 2001)

No significant correlations were found between $\mathrm{CH}_{4}$ efflux and the chemical properties of the soil in the mangrove of the Mojuim River estuary (Table 5). However, with an average flux of $4.70 \mathrm{mg} \mathrm{C} \mathrm{m}^{-2} \mathrm{~h}^{-1}$ and with extreme monthly and seasonal variation, more detailed studies are needed on $\mathrm{CH}_{4}$ efflux and on the relationship with methanotrophic bacteria and interactions with abiotic factors (mainly ammonia and sulfate).

\section{Conclusions}

Between latitude $0^{\circ}$ to $23.5^{\circ} \mathrm{S}$ the most recent estimate shows an emission of $2.3 \mathrm{~g} \mathrm{CO}_{2}$ $\mathrm{m}^{-2} \mathrm{~d}^{-1}$ (Rosentreter et al., 2018c). However, the efflux in the mangrove of the Mojuim River estuary was $6.7 \mathrm{~g} \mathrm{CO}_{2} \mathrm{~m}^{-2} \mathrm{~d}^{-1}$. For the same latitudinal range, the authors estimated an emission of $0.64 \mathrm{~g} \mathrm{CH}_{4} \mathrm{~m}^{-2} \mathrm{~d}^{-1}$, and we found an efflux of $0.13 \mathrm{~g} \mathrm{CH}_{4} \mathrm{~m}^{-2}$ $\mathrm{d}^{-1}$. Seasonality was important for $\mathrm{CH}_{4}$ efflux but did not influence $\mathrm{CO}_{2}$ efflux. Due to the rainfall variation compared to the climatology, the differences in fluxes may be an effect of global climate changes on the terrestrial biogeochemistry at the plant-soilatmosphere interface, making it necessary to extend this study for more years. Using the factor of 23 to convert the global warming potential of $\mathrm{CH}_{4}$ to $\mathrm{CO}_{2}$ (IPCC, 2001), the $\mathrm{CO}_{2}$ equivalent emission was $35.4 \mathrm{Mg} \mathrm{CO}_{2 \text {-eq }} \mathrm{ha}^{-1} \mathrm{yr}^{-1}$.

Microtopography should be considered when determining the efflux of $\mathrm{CO}_{2}$ and $\mathrm{CH}_{4}$ in mangrove forest in the Amazon estuary. The low topography in the mangrove forest of Rio Mojuim contained a higher concentration of organic carbon in the soil. However, it did not produce a higher $\mathrm{CO}_{2}$ efflux because this was negatively influenced by soil moisture, which was indifferent to $\mathrm{CH}_{4}$ efflux. $\mathrm{MO}, \mathrm{C} / \mathrm{N}$ ratio, and Eh were critical in soil microbial activity, which resulted in a variation in $\mathrm{CO}_{2}$ flux during the year and seasonal periods. In this sense, physicochemical properties of the soil are important for $\mathrm{CO}_{2}$ flux, especially in the rainy season; however, they did not influence $\mathrm{CH}_{4}$ fluxes.

Data availability: The data used in this article belong to the doctoral thesis of Saul Castellón, within the Postgraduate Program in Environmental Sciences, at the Federal University of Pará. Access to the data can be requested from Dr. Castellón (saulmarz22@gmail.com), which holds the set of all data used in this paper. 
Author contributions: SEMC and JHC designed the study and wrote the article with the help of JFB, MR, MLR, and CN. JFB assisted in the field experiment. MR provided logistical support in field activities.

Competing interests: The authors declare that they have no conflict of interest Acknowledgements: The authors are grateful to the Program of Alliances for Education and Training of the Organization of the American States and to Coimbra Group of Brazilian Universities, for the financial support, as well as to Paulo Sarmento for the assistance at laboratory analysis, and to Maridalva Ribeiro and Lucivaldo da Silva for the fieldwork assistance. Furthermore, the authors would like to thank the Laboratory of Biogeochemical Cycles (Geosciences Institute, Federal University of Pará) for the equipment provided for this research.

\section{References}

Abram, J. W. and Nedwell, D. B.: Inhibition of methanogenesis by sulphate reducing bacteria competing for transferred hydrogen, Arch. Microbiol., 117(1), 89-92, doi:10.1007/BF00689356, 1978.

Adame, M. F., Connolly, R. M., Turschwell, M. P., Lovelock, C. E., Fatoyinbo, T., Lagomasino, D., Goldberg, L. A., Holdorf, J., Friess, D. A., Sasmito, S. D., Sanderman, J., Sievers, M., Buelow, C., Kauffman, J. B., Bryan-Brown, D. and Brown, C. J.: Future carbon emissions from global mangrove forest loss, Glob. Chang. Biol., 27(12), 28562866, doi:10.1111/gcb.15571, 2021.

Allen, D., Dalal, R. C., Rennenberg, H. and Schmidt, S.: Seasonal variation in nitrous oxide and methane emissions from subtropical estuary and coastal mangrove sediments, Australia, Plant Biol., 13(1), 126-133, doi:10.1111/j.1438-8677.2010.00331.x, 2011.

Almeida, R. F. de, Mikhael, J. E. R., Franco, F. O., Santana, L. M. F. and Wendling, B.: Measuring the labile and recalcitrant pools of carbon and nitrogen in forested and agricultural soils: A study under tropical conditions, Forests, 10(7), 544, doi:10.3390/f10070544, 2019.

Alongi, D. M.: The contribution of mangrove ecosystems to global carbon cycling and greenhouse gas emissions, in Greenhouse gas and carbon balances in mangrove coastal ecosystems, edited by Y. Tateda, R. Upstill-Goddard, T. Goreau, D. M. Alongi, A. Nose, E. Kristensen, and G. Wattayakorn, pp. 1-10, Gendai Tosho, Kanagawa, Japan., 
2007.

Alongi, D. M.: The energetics of mangrove forests, Springer., 2009.

Alongi, D. M. and Christoffersen, P.: Benthic infauna and organism-sediment relations in a shallow, tropical coastal area: influence of outwelled mangrove detritus and physical disturbance, Mar. Ecol. Prog. Ser., 81(3), 229-245, doi:10.3354/meps081229, 1992.

Alongi, D. M. and Mukhopadhyay, S. K.: Contribution of mangroves to coastal carbon cycling in low latitude seas, Agric. For. Meteorol., 213, 266-272, doi:10.1016/j.agrformet.2014.10.005, 2015.

Angelov, M. N., Sung, S. J. S., Doong, R. Lou, Harms, W. R., Kormanik, P. P. and Black, C. C.: Long-and short-term flooding effects on survival and sink-source relationships of swamp-adapted tree species, Tree Physiol., 16(4), 477-484, doi:10.1093/treephys/16.5.477, 1996.

Araujo, A. S. F. de: Is the microwave irradiation a suitable method for measuring soil microbial biomass?, Rev. Environ. Sci. Biotechnol., 9(4), 317-321, doi:10.1007/s11157-010-9210-y, 2010.

Banerjee, S., Helgason, B., Wang, L., Winsley, T., Ferrari, B. C. and Siciliano, S. D.: Legacy effects of soil moisture on microbial community structure and $\mathrm{N} 2 \mathrm{O}$ emissions, Soil Biol. Biochem., 95, 40-50, doi:10.1016/j.soilbio.2015.12.004, 2016.

Bastviken, D., Tranvik, L. J., Downing, J. A., Crill, P. M. and Enrich-Prast, A.: Freshwater Methane Emissions Offset the Continental Carbon Sink, Science (80-. )., 331(6013), 50-50, doi:10.1126/science.1196808, 2011.

Bauza, J. F., Morell, J. M. and Corredor, J. E.: Biogeochemistry of Nitrous Oxide Production in the Red Mangrove (Rhizophora mangle) Forest Sediments, Estuar. Coast. Shelf Sci., 55(5), 697-704, doi:10.1006/ECSS.2001.0913, 2002.

Bertics, V. J., Sohm, J. A., Treude, T., Chow, C. E. T., Capone, D. G., Fuhrman, J. A. and Ziebis, W.: Burrowing deeper into benthic nitrogen cycling: The impact of Bioturbation on nitrogen fixation coupled to sulfate reduction, Mar. Ecol. Prog. Ser., 409, 1-15, doi:10.3354/meps08639, 2010.

Biswas, H., Mukhopadhyay, S. K., Sen, S. and Jana, T. K.: Spatial and temporal patterns of methane dynamics in the tropical mangrove dominated estuary, NE coast of 
Bay of Bengal, India, J. Mar. Syst., 68(1-2), 55-64, 2007.

Blagodatsky, S. and Smith, P.: Soil physics meets soil biology: Towards better mechanistic prediction of greenhouse gas emissions from soil, Soil Biol. Biochem., 47, 78-92, doi:10.1016/J.SOILBIO.2011.12.015, 2012.

Boetius, A., Ravenschlag, K., Schubert, C. J., Rickert, D., Widdel, F., Gleseke, A., Amann, R., Jørgensen, B. B., Witte, U. and Pfannkuche, O.: A marine microbial consortium apparently mediating anaerobic oxidation methane, Nature, 407(6804), 623626, doi:10.1038/35036572, 2000.

Borges, A. V., Abril, G., Darchambeau, F., Teodoru, C. R., Deborde, J., Vidal, L. O., Lambert, T. and Bouillon, S.: Divergent biophysical controls of aquatic $\mathrm{CO} 2$ and $\mathrm{CH} 4$ in the World's two largest rivers, Sci. Rep., 5, doi:10.1038/srep15614, 2015.

Borges, A. V., Abril, G. and Bouillon, S.: Carbon dynamics and $\mathrm{CO} 2$ and $\mathrm{CH} 4$ outgassing in the Mekong delta, Biogeosciences, 15(4), doi:10.5194/bg-15-1093-2018, 2018.

Bouillon, S., Borges, A. V., Castañeda-Moya, E., Diele, K., Dittmar, T., Duke, N. C., Kristensen, E., Lee, S. Y., Marchand, C., Middelburg, J. J., Rivera-Monroy, V. H., Smith, T. J. and Twilley, R. R.: Mangrove production and carbon sinks: A revision of global budget estimates, Global Biogeochem. Cycles, 22(2), doi:10.1029/2007GB003052, 2008.

Brookes, P. C., Landman, A., Pruden, G. and Jenkinson, D. S.: Chloroform fumigation and the release of soil nitrogen: A rapid direct extraction method to measure microbial biomass nitrogen in soil, Soil Biol. Biochem., 17(6), 837-842, doi:10.1016/00380717(85)90144-0, 1985.

Cameron, C., Hutley, L. B., Munksgaard, N. C., Phan, S., Aung, T., Thinn, T., Aye, W. M. and Lovelock, C. E.: Impact of an extreme monsoon on $\mathrm{CO} 2$ and $\mathrm{CH} 4$ fluxes from mangrove soils of the Ayeyarwady Delta, Myanmar, Sci. Total Environ., 760, 143422, doi:10.1016/J.SCITOTENV.2020.143422, 2021.

Chanda, A., Akhand, A., Manna, S., Dutta, S., Das, I., Hazra, S., Rao, K. H. and Dadhwal, V. K.: Measuring daytime CO2 fluxes from the inter-tidal mangrove soils of Indian Sundarbans, Environ. Earth Sci., 72(2), 417-427, doi:10.1007/s12665-013-2962$2,2014$. 
606 Chauhan, R., Datta, A., Ramanathan, A. and Adhya, T. K.: Factors influencing spatio607 temporal variation of methane and nitrous oxide emission from a tropical mangrove of 608 eastern coast of India, Atmos. Environ., 107, 95-106, 609 doi:10.1016/j.atmosenv.2015.02.006, 2015.

610 Chen, G. C., Tam, N. F. Y. and Ye, Y.: Spatial and seasonal variations of atmospheric $611 \mathrm{~N} 2 \mathrm{O}$ and $\mathrm{CO} 2$ fluxes from a subtropical mangrove swamp and their relationships with 612 soil characteristics, Soil Biol. Biochem., 48, 175-181, 613 doi:10.1016/j.soilbio.2012.01.029, 2012.

614 Chen, G. C. C., Tam, N. F. Y. F. Y. and Ye, Y.: Summer fluxes of atmospheric 615 greenhouse gases N2O, CH4 and CO2 from mangrove soil in South China, Sci. Total 616 Environ., 408(13), 2761-2767, doi:10.1016/j.scitotenv.2010.03.007, 2010.

617 Chowdhury, T. R., Bramer, L., Hoyt, D. W., Kim, Y. M., Metz, T. O., McCue, L. A., 618 Diefenderfer, H. L., Jansson, J. K. and Bailey, V.: Temporal dynamics of CO2 and CH4 619 loss potentials in response to rapid hydrological shifts in tidal freshwater wetland soils, 620 Ecol. Eng., 114, 104-114, doi:10.1016/j.ecoleng.2017.06.041, 2018.

621 Connell, W. E. and Patrick, W. H.: Sulfate reduction in soil: Effects of redox potential and pH, Science (80-. )., 159(3810), 86-87, doi:10.1126/science.159.3810.86, 1968. York, NY, USA., 1999. Scale on Spatial and Temporal Variations in $\mathrm{CH} 4, \mathrm{CO} 2$, and N2O Fluxes in a Forested Wetland, Water, Air, Soil Pollut., 223(1), 253-265, doi:10.1007/s11270-011-0855-0, 2012.

Davidson, E. A., Verchot, L. V., Cattanio, J. H., Ackerman, I. L. and Carvalho, J. E. M.: Effects of soil water content on soil respiration in forests and cattle pastures of eastern Amazonia, Biogeochemistry, 48(1), 53-69, doi:10.1023/a:1006204113917, 2000. Kanninen, M.: Mangroves among the most carbon-rich forests in the tropics, Nat. Geosci., 4(5), 293-297, doi:10.1038/ngeo1123, 2011. exchange fluxes of methane in the estuarine mangrove environment of the Sundarbans, 
637 NE coast of India, Atmos. Environ., 77, 631-639, doi:10.1016/j.atmosenv.2013.05.050, 6382013

639 Ehrenfeld, J. G.: Microsite differences in surface substrate characteristics in 640 Chamaecyparis swamps of the New Jersey Pinelands, Wetlands, 15(2), 183-189, 641 doi:10.1007/BF03160672, 1995.

642 El-Robrini, M., Alves, M. A. M. S., Souza Filho, P. W. M., El-Robrini M. H. S., Silva 643 Júnior, O. G. and França, C. F.: Atlas de Erosão e Progradação da zona costeira do 644 Estado do Pará - Região Amazônica: Áreas oceânica e estuarina, in Atlas de Erosão e 645 Progradação da Zona Costeira Brasileira, edited by D. Muehe, pp. 1-34, São Paulo., 6462006

647 EPA, E. P. A.: Inventory of U.S. Greenhouse Gas Emissions and Sinks: 1990-2015., 6482017.

649 Fernandes, W. A. A. and Pimentel, M. A. da S.: Dinâmica da paisagem no entorno da 650 RESEX marinha de São João da Ponta/PA: utilização de métricas e geoprocessamento, 651 Caminhos Geogr., 20(72), 326-344, doi:10.14393/RCG207247140, 2019.

652 Ferreira, A. S., Camargo, F. A. O. and Vidor, C.: Utilização de microondas na avaliação 653 da biomassa microbiana do solo, Rev. Bras. Ciência do Solo, 23(4), 991-996, 654 doi:10.1590/S0100-06831999000400026, 1999.

655 Ferreira, S. da S.: Entre marés e mangues: paisagens territorializadas por pescadores da 656 resex marinha de São João da Ponta/PA /, Universidade Federal do Pará., 2017.

657 França, C. F. de, Pimentel, M. A. D. S. and Neves, S. C. R.: Estrutura Paisagística De 658 São João Da Ponta, Nordeste Do Pará, Geogr. Ensino Pesqui., 20(1), 130, 659 doi:10.5902/2236499418331, 2016.

660 Frankignoulle, M.: Field measurements of air-sea CO, exchange', Limnol. Oceanogr., $66133(3), 313-322,1988$.

662 Friesen, S. D., Dunn, C. and Freeman, C.: Decomposition as a regulator of carbon 663 accretion in mangroves: a review, Ecol. Eng., 114, 173-178, 664 doi:10.1016/j.ecoleng.2017.06.069, 2018.

665 Fromard, F., Puig, H., Cadamuro, L., Marty, G., Betoulle, J. L. and Mougin, E.: 666 Structure, above-ground biomass and dynamics of mangrove ecosystems: new data 667 from French Guiana, Oecologia, 115(1), 39-53, doi:10.1007/s004420050489, 1998. 
668 Gao, G. F., Zhang, X. M., Li, P. F., Simon, M., Shen, Z. J., Chen, J., Gao, C. H. and 669 Zheng, H. L.: Examining Soil Carbon Gas (CO2, CH4) Emissions and the Effect on 670 Functional Microbial Abundances in the Zhangjiang Estuary Mangrove Reserve, J.

671 Coast. Res., 36(1), 54-62, doi:10.2112/JCOASTRES-D-18-00107.1, 2020.

672 Gardunho, D. C. .: Estimativas de biomassa acima do solo da floresta de mangue na 673 península de Ajuruteua, Bragança - PA, Unversidade Federal do Pará., 2017.

674 Hamilton, S. E. and Friess, D. A.: Global carbon stocks and potential emissions due to 675 mangrove deforestation from 2000 to 2012, Nat. Clim. Chang., 8(3), 676 doi:10.1038/s41558-018-0090-4, 2018.

677 He, Y., Guan, W., Xue, D., Liu, L., Peng, C., Liao, B., Hu, J., Zhu, Q., Yang, Y., Wang, 678 X., Zhou, G., Wu, Z. and Chen, H.: Comparison of methane emissions among invasive 679 and native mangrove species in Dongzhaigang, Hainan Island, Sci. Total Environ., 697, 680 133945, doi:10.1016/j.scitotenv.2019.133945, 2019.

681 Hegde, U., Chang, T.-C. and Yang, S.-S.: Methane and carbon dioxide emissions from 682 Shan-Chu-Ku landfill site in northern Taiwan., Chemosphere, 52(8), 1275-1285, doi:10.1016/S0045-6535(03)00352-7, 2003.

Herz, R.: Manguezais do Brasil, Instituto Oceanografico da Usp/Cirm, São Paulo, Brazil., 1991.

Howard, J., Hoyt, S., Isensee, K., Telszewski, M. and Pidgeon, E., Eds.: Coastal blue Carbon: Methods for assessing carbon stocks and emissions factors in mangroves, tidal salt marshes, and seagrasses, International Union for Conservation of Nature, Arlington, Virginia, USA. [online] Available from: www.ioc.unesco.org (Accessed 11 September 2019a), 2014.

Howard, J., Hoyt, S., Isensee, K., Telszewski, M. and Pidgeon, E.: Coastal Blue Carbon: Methods for Assessing Carbon Stocks and Emissions Factors in Mangroves, Tidal Salt Marshes, and Seagrasses, Arlington, Virginia, USA. [online] Available from: http://www.unesco.org/new/en/natural-sciences/ioc-oceans/sections-andprogrammes/ocean-sciences/ocean-carbon/coastal-blue-carbon/, 2014 b. IPCC: Climate Change 2001: Third Assessment Report of the IPCC, Cambridge., 2001. Islam, K. R. and Weil, R. R.: Microwave irradiation of soil for routine measurement of microbial biomass carbon, Biol. Fertil. Soils, 27(4), 408-416, 
doi:10.1007/s003740050451, 1998.

Kalembasa, S. J. and Jenkinson, D. S.: A comparative study of titrimetric and gavimetric methods for determination of organic carbon in soil, J. Sci. Food Agric., 24, 1085-1090, 1973.

Kauffman, B. J., Donato, D. and Adame, M. F.: Protocolo para la medición, monitoreo y reporte de la estructura, biomasa y reservas de carbono de los manglares, Bogor, Indonesia., 2013.

Kauffman, J. B., Bernardino, A. F., Ferreira, T. O., Giovannoni, L. R., De Gomes, L. E. O., Romero, D. J., Jimenez, L. C. Z. and Ruiz, F.: Carbon stocks of mangroves and salt marshes of the Amazon region, Brazil, Biol. Lett., 14(9), doi:10.1098/rsbl.2018.0208, 2018.

Kristensen, E., Bouillon, S., Dittmar, T. and Marchand, C.: Organic carbon dynamics in mangrove ecosystems: A review, Aquat. Bot., 89(2), 201-219, doi:10.1016/J.AQUABOT.2007.12.005, 2008.

Kristjansson, J. K., Schönheit, P. and Thauer, R. K.: Different Ks values for hydrogen of methanogenic bacteria and sulfate reducing bacteria: An explanation for the apparent inhibition of methanogenesis by sulfate, Arch. Microbiol., 131(3), 278-282, doi:10.1007/BF00405893, 1982.

Lekphet, S., Nitisoravut, S. and Adsavakulchai, S.: Estimating methane emissions from mangrove area in Ranong Province, Thailand, Songklanakarin J. Sci. Technol. ·, 27(1), 153-163 [online] Available from: https://www.researchgate.net/publication/26473398 (Accessed 29 January 2019), 2005.

Maher, D. T., Call, M., Santos, I. R. and Sanders, C. J.: Beyond burial: Lateral exchange is a significant atmospheric carbon sink in mangrove forests, Biol. Lett., 14(7), 1-4, doi:10.1098/rsbl.2018.0200, 2018.

Mahesh, P., Sreenivas, G., Rao, P. V. N., Dadhwal, V. K., Sai Krishna, S. V. S. and Mallikarjun, K.: High-precision surface-level $\mathrm{CO} 2$ and $\mathrm{CH} 4$ using off-axis integrated cavity output spectroscopy (OA-ICOS) over Shadnagar, India, Int. J. Remote Sens., 36(22), 5754-5765, doi:10.1080/01431161.2015.1104744, 2015.

Marchand, C.: Soil carbon stocks and burial rates along a mangrove forest chronosequence (French Guiana), For. Ecol. Manage., 384, 92-99, 
doi:10.1016/j.foreco.2016.10.030, 2017.

McEwing, K. R., Fisher, J. P. and Zona, D.: Environmental and vegetation controls on the spatial variability of $\mathrm{CH} 4$ emission from wet-sedge and tussock tundra ecosystems in the Arctic, Plant Soil, 388(1-2), 37-52, doi:10.1007/s11104-014-2377-1, 2015.

Megonigal, J. P. and Schlesinger, W. H.: Methane-limited methanotrophy in tidal freshwater swamps, Global Biogeochem. Cycles, 16(4), 35-1-35-10, doi:10.1029/2001GB001594, 2002.

Menezes, M. P. M. de, Berger, U. and Mehlig, U.: Mangrove vegetation in Amazonia : a review of studies from the coast of Pará and Maranhão States, north Brazil, Acta Amaz., 38(3), 403-420, doi:10.1590/S0044-59672008000300004, 2008.

Milucka, J., Kirf, M., Lu, L., Krupke, A., Lam, P., Littmann, S., Kuypers, M. M. M. and Schubert, C. J.: Methane oxidation coupled to oxygenic photosynthesis in anoxic waters, ISME J., 9(9), 1991-2002, doi:10.1038/ismej.2015.12, 2015.

Monz, C. A., Reuss, D. E. and Elliott, E. T.: Soil microbial biomass carbon and nitrogen estimates using $2450 \mathrm{MHz}$ microwave irradiation or chloroform fumigation followed by direct extraction, Agric. Ecosyst. Environ., 34(1-4), 55-63, doi:10.1016/01678809(91)90093-D, 1991.

Neue, H. U., Gaunt, J. L., Wang, Z. P., Becker-Heidmann, P. and Quijano, C.: Carbon in tropical wetlands, in Geoderma, vol. 79, pp. 163-185, Elsevier., 1997.

Nóbrega, G. N., Ferreira, T. O., Siqueira Neto, M., Queiroz, H. M., Artur, A. G., Mendonça, E. D. S., Silva, E. D. O. and Otero, X. L.: Edaphic factors controlling summer (rainy season) greenhouse gas emissions (CO2and $\mathrm{CH} 4)$ from semiarid mangrove soils (NE-Brazil), Sci. Total Environ., 542, 685-693, doi:10.1016/j.scitotenv.2015.10.108, 2016.

Norman, J. M., Kucharik, C. J., Gower, S. T., Baldocchi, D. D., Crill, P. M., Rayment, M., Savage, K. and Striegl, R. G.: A comparison of six methods for measuring soil-surface carbon dioxide fluxes, J. Geophys. Res. Atmos., 102(D24), 28771-28777, doi:10.1029/97JD01440@10.1002/(ISSN)2169-8996.BOREAS2, 1997.

Peel, M. C., Finlayson, B. L. and McMahon, T. A.: Updated world map of the KöppenGeiger climate classification, Hydrol. Earth Syst. Sci., 11(5), 1633-1644, doi:10.1002/ppp.421, 2007. 
761 Poffenbarger, H. J., Needelman, B. A. and Megonigal, J. P.: Salinity Influence on 762 Methane Emissions from Tidal Marshes, Wetlands, 31(5), 831-842, 763 doi:10.1007/s13157-011-0197-0, 2011.

764 Poungparn, S., Komiyama, A., Tanaka, A., Sangtiean, T., Maknual, C., Kato, S., 765 Tanapermpool, P. and Patanaponpaiboon, P.: Carbon Dioxide Emission through Soil

766 Respiration in a Secondary Mangrove Forest of Eastern Thailand, Source J. Trop. Ecol., 767 25(4), 393-400, doi:10.1017/S0266467409006154, 2009.

768 Prost, M. T., Mendes, A. C., Faure, J. F., Berredo, J. F., Sales, M. E. ., Furtado, L. G., 769 Santana, M. G., Silva, C. A., Nascimento, I. ., Gorayeb, I., Secco, M. F. and Luz, L.: 770 Manguezais e estuários da costa paraense: exemplo de estudo multidisciplinar integrado 771 (Marapanim e São Caetano de Odivelas), in Ecossistemas costeiros: impactos e gestão 772 ambiental, edited by M. T. Prost and A. Mendes, pp. 25-52, FUNTEC and Museu 773 Paraense Emílio Goeldi, Belém, Brazil., 2001. Purvaja, R. and Ramesh, R.: Natural and Anthropogenic Methane Emission from Coastal Wetlands of South India, Environ. Manage., 27(4), 547-557, doi:10.1007/s002670010169, 2001.

Purvaja, R., Ramesh, R. and Frenzel, P.: Plant-mediated methane emission from an Indian mangrove, Glob. Chang. Biol., 10(11), 1825-1834, doi:10.1111/j.13652486.2004.00834.x, 2004.

Reeburgh, W. S.: Oceanic Methane Biogeochemistry, Chem. Rev., 2, 486-513, doi:10.1021/cr050362v, 2007.

Robertson, A. I., Alongi, D. M. and Boto, K. G.: Food chains and carbon fluxes, in Coastal and Estuarine Studies, edited by A. I. Robertson and D. M. Alongi, pp. 293326, American Geophysical Union. [online] Available from: https://books.google.com.br/books?hl=pt-BR\&lr=\&id=-

786 uGA_Kpcr04C\&oi=fnd\&pg=PP7\&dq=Tropical+Mangrove+Ecosystems\&ots=bi4Rqwc

787 Rhv\&sig=KiIbq_4NObONARwOfblqo8YVSdI\&redir_esc=y\#v=onepage \&q=Tropical

788 Mangrove Ecosystems\&f=false (Accessed 22 July 2020), 1992.

789 Rocha, A. S.: Caracterização física do estuário do rio Mojuim em São Caetano de 790 Odivelas - Pa, Universidade Federal do Pará., 2015.

791 Rollnic, M., Costa, M. S., Medeiros, P. R. L. and Monteiro, S. M.: Tide Influence on 
792 Suspended Matter Transport in an Amazonian Estuary, J. Coast. Res., 85(85 (10085)),

793 121-125, doi:10.2112/SI85-025.1, 2018.

794 Rosentreter, J. A., Maher, D. T. T., Erler, D. V. V., Murray, R. and Eyre, B. D. D.:

795 Factors controlling seasonal $\mathrm{CO} 2$ and $\mathrm{CH} 4$ emissions in three tropical mangrove-

796 dominated estuaries in Australia, Estuar. Coast. Shelf Sci., 215(October), 69-82,

797 doi:10.1016/j.ecss.2018.10.003, 2018a.

798 Rosentreter, J. A., Maher, D. T., Erler, D. V., Murray, R. H. and Eyre, B. D.: Methane emissions partially offset "blue carbon" burial in mangroves, Sci. Adv., 4(6), eaao4985, doi:10.1126/sciadv.aao4985, 2018 b.

801 Rosentreter, J. A., Maher, D. . T., Erler, D. V. V., Murray, R. and Eyre, B. D. D.:

802 Seasonal and temporal CO2 dynamics in three tropical mangrove creeks - A revision of

803 global mangrove CO2 emissions, Geochim. Cosmochim. Acta, 222, 729-745, doi:10.1016/j.gca.2017.11.026, 2018c.

Roslev, P. and King, G. M.: Regulation of methane oxidation in a freshwater wetland by water table changes and anoxia, FEMS Microbiol. Ecol., 19(2), 105-115, doi:10.1111/j.1574-6941.1996.tb00203.x, 1996.

808 Sahu, S. K. and Kathiresan, K.: The age and species composition of mangrove forest 809 directly influence the net primary productivity and carbon sequestration potential, 810 Biocatal. Agric. Biotechnol., 20, 101235, doi:10.1016/j.bcab.2019.101235, 2019.

811 Salum, R. B., Souza-Filho, P. W. M., Simard, M., Silva, C. A., Fernandes, M. E. B., 812 Cougo, M. F., do Nascimento, W. and Rogers, K.: Improving mangrove above-ground 813 biomass estimates using LiDAR, Estuar. Coast. Shelf Sci., 236(June 2019), 106585, doi:10.1016/j.ecss.2020.106585, 2020.

815 Schmidt, M. W. I., Torn, M. S., Abiven, S., Dittmar, T., Guggenberger, G., Janssens, I. 816 A., Kleber, M., Kögel-Knabner, I., Lehmann, J., Manning, D. A. C., Nannipieri, P., 817 Rasse, D. P., Weiner, S. and Trumbore, S. E.: Persistence of soil organic matter as an 818 ecosystem property, Nature, 478(7367), 49-56, doi:10.1038/nature10386, 2011.

819 Segarra, K. E. A., Schubotz, F., Samarkin, V., Yoshinaga, M. Y., Hinrichs, K. U. and Joye, S. B.: High rates of anaerobic methane oxidation in freshwater wetlands reduce potential atmospheric methane emissions, Nat. Commun., 6(1), 1-8, doi:10.1038/ncomms8477, 2015. 
Shiau, Y. J. and Chiu, C. Y.: Biogeochemical processes of $\mathrm{C}$ and $\mathrm{N}$ in the soil of mangrove forest ecosystems, Forests, 11(5), 1-15, doi:10.3390/F11050492, 2020.

Shiau, Y. J., Lin, M. F., Tan, C. C., Tian, G. and Chiu, C. Y.: Assessing N2 fixation in estuarine mangrove soils, Estuar. Coast. Shelf Sci., 189, 84-89, doi:10.1016/j.ecss.2017.03.005, 2017.

Shiau, Y. J., Cai, Y., Lin, Y. Te, Jia, Z. and Chiu, C. Y.: Community Structure of Active Aerobic Methanotrophs in Red Mangrove (Kandelia obovata) Soils Under Different Frequency of Tides, Microb. Ecol., 75(3), 761-770, doi:10.1007/s00248-017-1080-1, 2018.

Souza Filho, P. W. M.: Costa de manguezais de macromaré da Amazônia: cenários morfológicos, mapeamento e quantificação de áreas usando dados de sensores remotos, Rev. Bras. Geofísica, 23(4), 427-435, doi:10.1590/S0102-261X2005000400006, 2005. Sparling, G. P. and West, A. W.: A direct extraction method to estimate soil microbial C: calibration in situ using microbial respiration and 14C labelled cells, Soil Biol. Biochem., 20(3), 337-343, doi:10.1016/0038-0717(88)90014-4, 1988.

Stevenson, F. J. and Cole, M. A.: Cycles of Soils: Carbon, Nitrogen, Phosphorus, Sulfur, Micronutrients, 2nd Editio., Wiley, New York, NY, USA. [online] Available from: https://www.wiley.com/enus/Cycles+of+Soils $\% 3 \mathrm{~A}+$ Carbon $\% 2 \mathrm{C}+$ Nitrogen $\% 2 \mathrm{C}+\mathrm{Phosphorus} \% 2 \mathrm{C}+\mathrm{Sulfur} \% 2 \mathrm{C}+\mathrm{M}$ icronutrients\%2C+2nd+Edition-p-9780471320715 (Accessed 27 May 2021), 1999.

Sundqvist, E., Vestin, P., Crill, P., Persson, T. and Lindroth, A.: Short-term effects of thinning, clear-cutting and stump harvesting on methane exchange in a boreal forest, Biogeosciences, 11(21), 6095-6105, doi:10.5194/bg-11-6095-2014, 2014.

Valentim, M., Monteiro, S. and Rollnic, M.: The Influence of Seasonality on Haline Zones in An Amazonian Estuary, J. Coast. Res., 85, 76-80, doi:10.2112/SI85-016.1, 2018.

Valentine, D. L.: Emerging Topics in Marine Methane Biogeochemistry, Ann. Rev. Mar. Sci., 3(1), 147-171, doi:10.1146/annurev-marine-120709-142734, 2011.

Vance, E. D., Brookes, P. C. and Jenkinson, D. S.: An extraction method for measuring soil microbial biomass C, Soil Biol. Biochem., 19(6), 703-707, doi:10.1016/00380717(87)90052-6, 1987. 
https://doi.org/10.5194/bg-2021-325

Preprint. Discussion started: 4 February 2022

(C) Author(s) 2022. CC BY 4.0 License.

854 Verchot, L. V., Davidson, E. A., Cattânio, J. H. and Ackerman, I. L.: Land-use change

855 and biogeochemical controls of methane fluxes in soils of eastern Amazonia,

856 Ecosystems, 3(1), 41-56, doi:10.1007/s100210000009, 2000.

857 Welsh, D. T., Bourgués, S., De Wit, R. and Herbert, R. A.: Seasonal variations in

858 nitrogen-fixation (acetylene reduction) and sulphate-reduction rates in the rhizosphere

859 of Zostera noltii: Nitrogen fixation by sulphate-reducing bacteria, Mar. Biol., 125(4),

860 619-628, doi:10.1007/BF00349243, 1996.

861 Whalen, S. C.: Biogeochemistry of Methane Exchange between Natural Wetlands and

862 the Atmosphere, Environ. Eng. Sci., 22(1), 73-94, doi:10.1089/ees.2005.22.73, 2005.

863 Yang, S. S. and Chang, H. L.: Effect of environmental conditions on methane

864 production and emission from paddy soil, Agric. Ecosyst. Environ., 69(1), 69-80,

865 doi:10.1016/S0167-8809(98)00098-X, 1998.

866 